\title{
Carbon Isotopic Evidence for Biodegradation of Organic Contaminants in the Shallow Vadose Zone of the Radioactive Waste Management Complex
}

\author{
Mark E. Conrad* and Donald J. DePaolo \\ Earth Sciences Division, E.O. Lawrence Berkeley National Laboratory
}

Submitted to

Vadose Zone Journal

May 20, 2003

Mark E. Conrad*, Earth Sciences Division, MS 70A-4418, E.O. Lawrence Berkeley National Laboratory, Berkeley, CA 94720 (MSConrad@lbl.gov)

Donald J. DePaolo, Earth Sciences Division, MS 90R-1116, E.O. Lawrence Berkeley National Laboratory, Berkeley, CA 94720 (depaolo@eps.berkeley.edu) 


\begin{abstract}
Waste material buried in drums in the shallow subsurface at the Radioactive Waste Management Facility (RWMC) of the Idaho National Engineering and Environmental Laboratory (INEEL) contained significant amounts of organic compounds including lubricating oils and chlorinated solvents. $\mathrm{CO}_{2}$ concentrations in pore gas samples from monitoring wells in the vicinity of the disposal pits are 3 to 5 times higher than the concentrations in nearby background wells. The stable carbon isotope ratios $\left(\delta^{13} \mathrm{C}\right.$ values $)$ of $\mathrm{CO}_{2}$ from the disposal pits averaged 2.4\%o less than $\mathrm{CO}_{2}$ from the background wells, indicating that the elevated $\mathrm{CO}_{2}$ concentrations around the pits were derived from source materials with $\delta^{13} \mathrm{C}$ values in the range of $-24 \%$ to $-29 \%$. These $\delta^{13} \mathrm{C}$ values are typical of lubricating oils, but higher than most solvents. The radiocarbon $\left({ }^{14} \mathrm{C}\right)$ contents of $\mathrm{CO}_{2}$ across most of the site were significantly elevated above modern concentrations due to reactor blocks buried in a subsurface vault at the site. However, several samples collected from the high- $\mathrm{CO}_{2}$ zone on the far side of the RWMC from the reactor blocks had very low ${ }^{14} \mathrm{C}$ contents (less than 0.13 times modern), confirming production from lubricating oils manufactured from fossil hydrocarbons. The magnitude of the $\mathrm{CO}_{2}$ anomaly observed at the site is consistent with intrinsic biodegradation rates on the order of 0.5 to 3.0 metric tons of carbon per year.
\end{abstract}




\section{Introduction}

Intrinsic bioremediation - the use of naturally occurring microorganisms to convert organic contaminants to harmless forms - is gaining widespread acceptance as a viable method for remediating sites contaminated with hydrocarbon compounds. In an extensive study of groundwater sites impacted by leaking underground fuel tanks, Rice et al. (1995) were able to demonstrate that natural processes, especially under aerobic conditions, quickly degrade most petroleum hydrocarbons. Wedemeier et al. (1999) have identified a range of conditions that are favorable for biodegradation of chlorinated solvents (e.g., trichloroethene, carbon tetrachloride). For the most part, however, these studies have been focused on groundwater contamination, leaving the potential for intrinsic biodegradation of organic contaminants in the unsaturated zone poorly understood.

One of the primary challenges for determining the efficacy of intrinsic bioremediation as a remediation option is monitoring its progress in the subsurface. One technique is to try to detect changes in the concentrations of metabolic byproducts of the biologic activity. For aerobic metabolism of organic compounds, the primary product is $\mathrm{CO}_{2}$. Increased $\mathrm{CO}_{2}$ concentrations in the vicinity of organic contaminants can indicate that biodegradation of the contaminants is occurring. However, this interpretation can be complicated by other potential sources of $\mathrm{CO}_{2}$ such as plant root respiration, biodegradation of natural soil organic matter and dissolution of carbonate minerals. To further constrain the origin of subsurface $\mathrm{CO}_{2}$, the stable carbon isotope ratio ( $\delta^{13} \mathrm{C}$ value) of the $\mathrm{CO}_{2}$ can be analyzed. Hydrocarbon compounds are generally relatively depleted in ${ }^{13} \mathrm{C}$ (low $\delta^{13} \mathrm{C}$ values) relative to most other sources of carbon (Schoell, 1984). Therefore, microbial metabolism of compounds manufactured from hydrocarbons tends to

produce soil gas $\mathrm{CO}_{2}$ with low $\delta^{13} \mathrm{C}$ values where significant degradation of hydrocarbons is 
occurring. A number of field studies of aerobic hydrocarbon bioremediation have noted this effect above groundwater plumes (Suchomel et al., 1990; Ostendorf and Kampbell, 1991; Aggarwal and Hinchee, 1991; Feng et al., 2000).

However, $\delta^{13} \mathrm{C}$ analyses alone may lead to ambiguous results, as there can be significant overlap between the stable carbon isotope ratios of the contaminants and background organic matter. In addition, microbial processes such as methanogenesis and methane oxidation can cause the isotopic compositions of $\mathrm{CO}_{2}$ produced to be enriched rather than depleted in ${ }^{13} \mathrm{C}$ (Revesz et al., 1995; Landmeyer et al., 1996; Conrad et al., 1999). One method of resolving most of the uncertainties associated with stable carbon isotopic measurements is to measure the ${ }^{14} \mathrm{C}$ content of the metabolic byproducts (Suchomel et al., 1990; Conrad et al., 1997; Aelion et al., 1997). The ${ }^{14} \mathrm{C}$ content of natural organic matter in near surface environments is usually at or near modern atmospheric levels, whereas fossil fuels have no measurable ${ }^{14} \mathrm{C}$. Further, the variations in ${ }^{14} \mathrm{C} /{ }^{12} \mathrm{C}$ ratios are sufficiently large that they are not significantly affected by isotopic fractionation attending microbial processes.

In this paper, we present data on the concentrations, $\delta^{13} \mathrm{C}$ and ${ }^{14} \mathrm{C}$ values of $\mathrm{CO}_{2}$ in pore gas samples collected from the vadose zone in and around the Radioactive Waste Management Complex (RWMC) at the Idaho National Engineering and Environmental Laboratory (INEEL). These data clearly indicate that extensive biodegradation of organic contaminants in the shallow vadose zone is occurring at the site.

\section{Site Background}

The RWMC is located in the southwest section of the INEEL on the Snake River Plain in eastern Idaho (inset of Fig. 1). The geology of the upper $200 \mathrm{~m}$ at the RWMC site consists of 10 
basalt-flow groups with 7 major sedimentary interbed units ranging in age from 100 ka to 600 ka. Each basalt group is made up of 1 to 5 separate flows erupted from a common source during periods of volcanic activity lasting less than 200 years (Anderson and Lewis, 1989). The sedimentary interbeds consist of river and lake sediments, paleosols and wind-blown dust deposited during periods of volcanic quiescence. These interbeds are up to $10 \mathrm{~m}$ in thickness, constituting approximately $10 \%$ of the total stratigraphic section (Anderson and Lewis, 1989). The unsaturated zone is approximately $180 \mathrm{~m}$ thick and contains perched water horizons above some of the interbeds.

Significant amounts of radioactive waste resulting from Department of Energy activities are stored at the RWMC. Fig. 1 contains a map of the site, with the locations of the wells sampled for this project. The site is divided into two sections, the Subsurface Disposal Area (SDA) and the Transuranic Storage Area (TSA). Most of the waste in the SDA is contained in drums buried in shallow pits (approximately $1.5 \mathrm{~m}$ deep) that are shown on Fig. 1. In addition to the radionuclides, the waste drums also contain significant amounts of organic compounds. The total amount of organics originally deposited in the pits is estimated at approximately 148 metric tons of carbon tetrachloride, 138 metric tons of other chlorinated solvents (e.g., perchloroethene, trichloroethene and trichloroethane) and 125 metric tons of lubricating oils (Anderson and Lewis, 1989). Leakage from the drums has resulted in a vapor-phase, chlorinated solvent plume in the vadose zone and low levels of organics in the groundwater. In addition, various other waste materials are stored in the SDA, including six beryllium reflector blocks from the Advanced Test Reactor at the INEEL buried in a soil vault in the southeast section of the SDA (Fig. 1). The waste at the TSA is all stored in temporary, above ground containers. 
To remediate the solvent plume emanating from the disposal pits in the SDA, a vapor extraction system was installed at the site and began operation shortly before this project began (Fall of 1996). The system originally consisted of three treatment units, but after continuing problems with one of the units (Unit $\mathrm{C}$ on Fig. 1), that unit was shut down. The other two units also had significant periods of down time for repairs and maintenance.

During operation, the vapor extraction units pump pore gas out of extraction wells. The chlorinated solvents are stripped from the pore gas using activated charcoal and the air is released to the atmosphere. The extent of influence of the system on subsurface processes is poorly understood. The contaminant levels in the extracted vapors drop to very low levels when the extraction units are in operation, but rebound quickly when the units are shut down. One of the secondary goals of this project was to determine the extent of influence of the extraction wells.

\section{Methods of Study}

To determine the extent of natural biodegradation of organic contaminants at the RWMC, more than 200 gas samples were collected from 57 sampling ports in 24 different monitoring wells over a two-year period (October, 1996 through November, 1998). These samples were taken from a combination of shallow soil gas probes and deep gas sampling ports (to almost 180 $\mathrm{m}$ below ground surface) installed in monitoring wells in and around the RWMC. The details of the installation and subsurface characteristics for the deep vapor sampling ports is contained in a report by Parsons Engineering Sciences (1995) and summarized here. The vapor sampling ports

were installed on the outside of the well casing. The sampling intervals are filled with size 4-6 
sand. Intervals with only vapor ports are typically about $1.5 \mathrm{~m}$ in length, but intervals where the well casing are screened for vapor extraction are as long as $10 \mathrm{~m}$. The sand-filled intervals are sealed above and below with bentonite layers ranging from 0.6 to $2.0 \mathrm{~m}$ thick. The rest of the casing was grouted in place. The vapor ports were constructed of $3 / 8 "(\sim 9.5 \mathrm{~mm})$ outer diameter stainless steel tubing with $21 / 8 "(\sim 3.2 \mathrm{~mm})$ diameter perforations every $7.6 \mathrm{~cm}$. The ports were connected to the surface with $3 / 8$ " tubing and are kept sealed when not being used. Several of the vapor sampling ports were sealed and could not be used, and at least one port $(9 \mathrm{~V}-2)$ became sealed during this study.

The samples were collected in 1- or 3-liter Tedlar® bags from selected vapor ports using a portable diaphragm pump after purging the port for a specified time period (approximately equal to the time required to pump 3 times the volume of the sample tubing). The concentrations of $\mathrm{N}_{2}, \mathrm{O}_{2}$ and $\mathrm{CO}_{2}$ in the samples were analyzed by gas chromatograph. These analyses are accurate to $\pm 0.1 \%$. Samples containing low concentrations of $\mathrm{CO}_{2}(<0.2 \%)$ were analyzed using an infrared gas analyzer (Li-Cor $\left.{ }^{\circledR}\right)$ and are accurate to within $\pm 1 \%$ of the measured values. $\mathrm{CO}_{2}$ concentrations measured by both techniques are given in Table 1 . The $\mathrm{CO}_{2}$ concentrations measured for duplicate samples collected during the same sampling trip were within $\pm 10 \%$ of each other.

For isotopic analyses, the $\mathrm{CO}_{2}$ was extracted from the gas samples by bubbling it through a solution of $5 \mathrm{~N} \mathrm{NaOH}$. Aliquots of the $\mathrm{CO}_{2}$ were then released from the $\mathrm{NaOH}$ solutions by acidifying them with $100 \% \mathrm{H}_{3} \mathrm{PO}_{4}$ in evacuated tubes. The evolved $\mathrm{CO}_{2}$ was then separated from the water by passing it through a trap with a $-90^{\circ} \mathrm{C}$ methanol slush and freezing it into a tube at liquid $\mathrm{N}_{2}$ temperature. This technique was more time consuming than standard cryogenic techniques used to separate $\mathrm{CO}_{2}$ from air samples, but was necessary in order to avoid trapping 
vapor-phase hydrocarbon compounds with the $\mathrm{CO}_{2}$. The stable carbon isotope ratios of the samples were determined using the VG Prism Isotope Ratio Mass Spectrometer at the Center for Isotope Geochemistry (CIG) at the Lawrence Berkeley National Laboratory (LBNL). The isotope ratios are reported relative to Vienna PeeDee Belemnite using the per mil notation (\%o), where:

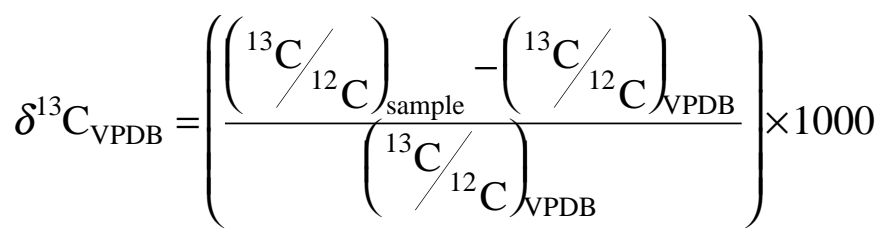

Variations between the $\delta^{13} \mathrm{C}$ values of separately prepared aliquots of the $\mathrm{NaOH}$ solution were generally within $\pm 0.2 \%$. Duplicate samples collected in the field were within $\pm 0.5 \%$. The $\delta^{13} \mathrm{C}$ values are given in Table 1 (where duplicate analyses were done, only an average value is reported).

The ${ }^{14} \mathrm{C}$ content of $\mathrm{CO}_{2}$ aliquots split from the stable isotope samples were analyzed at the Center for Accelerator Mass Spectrometry (CAMS) at Lawrence Livermore National Laboratory. $\mathrm{CO}_{2}$ was converted to graphite following the procedures documented by Lloyd et al. (1991). The ${ }^{14} \mathrm{C}$ content of the graphite was then analyzed using the CAMS accelerator. The results from these analyses are reported as a fraction of modern, pre-1950, carbon (values greater than 1 represent samples containing radiocarbon produced during above-ground testing of nuclear weapons). The precision of the analyses is $\leq 0.01$ times modern carbon. 


\section{Results and Discussion}

Table 1 contains a compilation of the data collected for this study. $\mathrm{CO}_{2}$ concentrations ranged from $66 \mathrm{ppm}$ (considerably less than the $\sim 380 \mathrm{ppm}$ concentration in the atmosphere) to $2.1 \%$ by volume. The measured $\delta^{13} \mathrm{C}$ values were between $-24.3 \%$ and $-9.8 \%$ and the ${ }^{14} \mathrm{C}$ concentrations ranged from below the lower detection limit of the CAMS accelerator $(<0.01$ times modern) to greater than 5 times modern (the upper detection limit of the CAMS accelerator).

\section{Background $\mathrm{CO}_{2}$}

Samples were collected from 3 sites to determine the background $\mathrm{CO}_{2}$ signal in the vicinity of the RWMC. Boreholes VVE-6 and M6S are located approximately $400 \mathrm{~m}$ southeast of the TSA and more than $1 \mathrm{~km}$ from the SDA on a knoll overlooking the site ( $20 \mathrm{~m}$ in elevation above the level of the SDA). 29 samples from 5 depths were collected from these wells over the duration of the project. The WWW boreholes are located $\sim 300 \mathrm{~m}$ west of the SDA and $700 \mathrm{~m}$ from the nearest burial pit. 11 samples from 4 different depths were collected from this site during the second year of the study. In addition, a single sample was collected from port 6 in borehole 77-1 during the early part of the project. This borehole is located about $250 \mathrm{~m}$ from the SDA and $500 \mathrm{~m}$ from the nearest burial pit.

The $\mathrm{CO}_{2}$ concentrations and isotopic compositions measured for the samples from the background wells are plotted with the data for samples from the SDA on Fig. 2. The $\mathrm{CO}_{2}$ concentrations were variable, but generally decreased from approximately $0.3 \%$ in the shallow subsurface $(<5 \mathrm{~m})$ to less than $0.1 \%$ below $100 \mathrm{~m}$. This is consistent with higher levels of 
biologic activity (e.g., root respiration, microbial degradation of organic matter) in the shallow soils. These data establish that background $\mathrm{CO}_{2}$ concentrations between 10 and $70 \mathrm{~m}$ deep are between 0.1 and $0.4 \%$ and average about $0.2 \%$.

The $\delta^{13} \mathrm{C}$ values of the $\mathrm{CO}_{2}$ from the background wells ranged from $-12.1 \%$ to $-22.1 \%$, but most ( 35 of 40 samples) were between $-17 \%$ and $-21 \%$. The $\mathrm{CO}_{2}$ in the shallowest samples were slightly more depleted in ${ }^{13} \mathrm{C}$ than the deeper samples, which is consistent with increased biologic activity in the shallow soils. Between 10 and $70 \mathrm{~m}$ depth, the average $\delta^{13} \mathrm{C}$ value is $-18.2 \%$ with a $1 \sigma$ standard deviation of $1 \%$.

The ${ }^{14} \mathrm{C}$ contents of 4 samples from the VVE-6/M6S site were measured. Two of the samples had ${ }^{14} \mathrm{C}$ contents close to or slightly less than atmospheric $\mathrm{CO}_{2}$ (currently at about 1.12 times modern due to production of ${ }^{14} \mathrm{C}$ from above-ground nuclear testing). Two of the samples, however, had ${ }^{14} \mathrm{C}$ contents above atmospheric values. The Be-reflector blocks buried in the southeast corner of the SDA, over $1 \mathrm{~km}$ from the VVE-6 and M6S, are the most likely source of the ${ }^{14} \mathrm{CO}_{2}$ (Fig. 1). Transuranics are also stored in the TSA, but these are all in above ground containers. This clearly indicates that VVE-6 and M6S have been influenced by the activities at the site. However, concentrations of radiocarbon in soil gas $\mathrm{CO}_{2}$ from adjacent to the vault containing the Be-reflector blocks are up to 4000 times modern (Ritter and McElroy, 1999). Therefore, the total input of $\mathrm{CO}_{2}$ from the SDA required to produce the ${ }^{14} \mathrm{C}$ content measured in VVE-6 is small $(\sim 0.1 \%)$.

\section{$\mathrm{CO}_{2}$ in the SDA}

The $\mathrm{CO}_{2}$ concentrations measured for pore gas samples from the vicinity of the SDA were generally significantly higher than the $\mathrm{CO}_{2}$ concentrations in the background wells. The highest 
$\mathrm{CO}_{2}$ concentration measured in any of the background samples was $0.4 \%$. Within the SDA, nearly half of the samples ( 74 of 151 ) contained more than $0.4 \% \mathrm{CO}_{2}$ and a significant number (25) were $1.0 \%$ or higher (Fig. 2). There were some very high concentration samples (to $>2 \%$ $\left.\mathrm{CO}_{2}\right)$ in the shallow subsurface $(<10 \mathrm{~m}$ depth). Samples from the same sample locations were highly variable, with a weak seasonal correlation related to the growing season of surface plants. Concentrations tended to be higher during the spring and early summer and lower during the late summer and fall. More significantly, there was a zone of highly elevated $\mathrm{CO}_{2}$ concentrations between 15 and $35 \mathrm{~m}$ depth. The relationship between these samples and the waste material in the disposal pits is discussed below.

Location of Elevated $\mathrm{CO}_{2}$ Zone. The highest $\mathrm{CO}_{2}$ concentrations in the deeper vadose zone of the SDA were concentrated in the vicinity of the burial pits. Fig. 3 contains a series of maps with the average $\mathrm{CO}_{2}$ concentrations for samples from between 10 to $25 \mathrm{~m}$ depth, 25 to $40 \mathrm{~m}$ depth and 40 to $70 \mathrm{~m}$ depth. There is an area of elevated $\mathrm{CO}_{2}$ just to the north of Pit 4 and 6 , especially at 10-25 m depth. Fig. 4 is an east-west longitudinal section passing through the center of the high $\mathrm{CO}_{2}$ zone (all data from sampling points within $100 \mathrm{~m}$ of the section have been projected onto the section). Also shown on this figure are the extent of surficial alluvium and the sedimentary interbeds. Most of the higher $\mathrm{CO}_{2}$ concentrations $(>0.3 \%)$ were measured for samples taken from the vicinity of the burial pits, above the B-C interbed (one of the more continuous interbed units in the RWMC subsurface). Within this area, however, there were some distinctive fluctuations in the depth of the $\mathrm{CO}_{2}$ contours. Most of this variability is probably the result of the vapor extraction units that began operating at the site shortly before the beginning of this study. 
The Impact of the Vapor Extraction Units. The effect of the vapor extraction units on the $\mathrm{CO}_{2}$ concentrations is clearly illustrated in Fig. 5. Borehole 8801 is immediately adjacent to vapor extraction unit A. When in operation, the unit pulls pore gas from ports in several wells, including 8901 which is located approximately $20 \mathrm{~m}$ from 8801 . Operation of this unit began during 1996, but it was shut down for repairs and maintenance from March through the beginning of July in 1997. During that time, the concentrations of $\mathrm{CO}_{2}$ increased in all three sampling ports in borehole 8801. After the unit began regular operation in July, the $\mathrm{CO}_{2}$ concentrations all three ports decreased significantly. There was another period of extended downtime during the spring and early summer of 1998 that also resulted in a rebound in the $\mathrm{CO}_{2}$ concentrations in 8801 . It is clear that the $\mathrm{CO}_{2}$ concentrations in the subsurface immediately adjacent to the vapor extraction units are drawn down when the units are in operation. The $\mathrm{CO}_{2}$ concentration in 8801-4 (the shallowest port in 8801 ) would have probably averaged close to $1 \%$ $\mathrm{CO}_{2}$ without the influence of the vapor extraction units.

Other wells used for vapor extraction while samples were collected include $7 \mathrm{~V}, 4 \mathrm{E}, 3 \mathrm{~V}$ and 2E. The average $\mathrm{CO}_{2}$ concentrations in the vicinity of all of these wells plotted on Fig. 4 were significantly lower than in the other wells. In fact, the vapor extraction units had no perceptible affect on the $\mathrm{CO}_{2}$ concentrations in ports at any significant distance from the units (e.g., 3E and D-02 which are located $\sim 80 \mathrm{~m}$ from the nearest extraction wells), suggesting that the extraction units had limited lateral areas of influence.

Sub-ambient $\mathrm{CO}_{2}$ Concentrations. There were also several samples collected from ports 3 and 4 in borehole M10S that had $\mathrm{CO}_{2}$ concentrations below atmospheric levels $(\sim 380 \mathrm{ppm})$. 
This is most likely caused by exchange with pore water DIC. At higher $\mathrm{pHs}$, the equilibrium concentration of DIC in water shifts from dissolved $\mathrm{CO}_{2}$ to carbonate and bicarbonate ions, resulting in lower $\mathrm{CO}_{2}$ pressures in the gas phase. The existence of such low $\mathrm{CO}_{2}$ concentrations in the samples from M10S suggests that chemical trapping of $\mathrm{CO}_{2}$ must be occurring in the vicinity of those sampling ports.

\section{The Source of Elevated $\mathrm{CO}_{2}$ in the SDA}

The concentration data clearly indicate that the elevated $\mathrm{CO}_{2}$ in the SDA is associated with the disposal trenches. There are a variety of potential sources for the additional $\mathrm{CO}_{2}$ such as degradation of the lubricating oils and/or chlorinated solvents in the waste, degradation of other organic matter buried with the waste, and differences in plant cover at the surface. The origin of the $\mathrm{CO}_{2}$ cannot be determined from the concentration data alone, however, the carbon isotope data help place additional constraints on the source of the $\mathrm{CO}_{2}$.

The average $\delta^{13} \mathrm{C}$ value of $\mathrm{CO}_{2}$ in samples from between 10 and $70 \mathrm{~m}$ depth in the high- $\mathrm{CO}_{2}$ zone of the SDA (defined by the area within the $0.3 \%$ contour on Fig. $3 a$ ) is $-20.6 \%$. This is $2.4 \%$ lower than the average $\delta^{13} \mathrm{C}$ value of $\mathrm{CO}_{2}$ in samples from the same depth range in the background wells (-18.2\%o). This relationship is further demonstrated on Fig. 6, which is a plot of the inverse $\mathrm{CO}_{2}$ concentration versus the $\delta^{13} \mathrm{C}$ values of $\mathrm{CO}_{2}$ in samples from the high- $\mathrm{CO}_{2}$ zone. Allowing for carbon isotopic fractionation of $4.4 \%$ resulting from diffusive loss of $\mathrm{CO}_{2}$ to the atmosphere (Cerling, 1984), this indicates that the source of the $\mathrm{CO}_{2}$ has a $\delta^{13} \mathrm{C}$ value between $-24 \%$ and $-29 \%$. $\mathrm{CO}_{2}$ produced from aerobic biodegradation of organic compounds is generally $1-3 \%$ lower than the substrate, suggesting that the source of the $\mathrm{CO}_{2}$ in the SDA was between $-21 \%$ to $-28 \%$. This is within the range of $\delta^{13} \mathrm{C}$ values that would be expected for 
petroleum hydrocarbons (e.g., the lubricating oils). However, plant respiration and/or microbial degradation of natural organic matter could also produce $\mathrm{CO}_{2}$ with $\delta^{13} \mathrm{C}$ values in this range. Although there is no obvious increase in the amount of natural organic matter in the vicinity of the disposal pits, it is possible that the activities at the site (e.g., wetting down the ground for dust abatement) might have caused enhanced biological activity in the near surface.

The ${ }^{14} \mathrm{C}$ contents of a limited number of $\mathrm{CO}_{2}$ samples were analyzed to address the issue of whether or not the source of the high $\mathrm{CO}_{2}$ was derived from the organic contaminants or from augmented natural activity. Interpreting this data was complicated by the beryllium reflector blocks buried in the soil vault in the southeast corner of the SDA, which are a source for high ${ }^{14} \mathrm{C}$ $\mathrm{CO}_{2}$. Because that source is so high ( $>4000$ times modern; Ritter and McElroy, 1999), relatively small inputs from the reflector blocks will dominate the measured ${ }^{14} \mathrm{C}$ signal, as was observed for the samples from VVE-6 (one of the background wells). Fig. 7 is a map of the site with all of the available radiocarbon data. Most of the samples from the SDA have ${ }^{14} \mathrm{C}$ contents greater than 5 times modern (the upper detection limit of the CAMS accelerator). However, 3 samples taken from two of the monitoring wells $(7 \mathrm{~V}$ and $9 \mathrm{~V})$ have ${ }^{14} \mathrm{C}$ contents between 0.00 and 0.13 times modern. These wells are on the opposite side of the disposal trenches from the beryllium reflector blocks, and are most likely to be representative of the ${ }^{14} \mathrm{C}$ contents of the elevated $\mathrm{CO}_{2}$ source.

The only possible sources of such low ${ }^{14} \mathrm{C} \mathrm{CO}_{2}$ in the SDA are organic compounds derived from fossil hydrocarbons (e.g., lubricating oils, chlorinated solvents) and "old" carbonates in the sedimentary interbeds. If the source of the low- ${ }^{14} \mathrm{C} \mathrm{CO}_{2}$ was dissolution of carbonates, the $\delta^{13} \mathrm{C}$ values of the $\mathrm{CO}_{2}$ should be much higher. No measurements have been made of calcite from the RWMC site, but calcite from the TAN site at the INEEL has $\delta^{13} \mathrm{C}$ values ranging from -3 to $-7 \%$ 
(Tobin et al., 1997). Assuming that calcite at the RWMC has a similar range, the $\delta^{13} \mathrm{C}$ value of $\mathrm{CO}_{2}$ produced from dissolution of the calcite would be between $-9 \%$ and $-15 \%$, depending on the temperature and $\mathrm{pH}$ of the pore waters at the time of dissolution (Wigley et al., 1975). As discussed above, the source of the $\mathrm{CO}_{2}$ was significantly more depleted in ${ }^{13} \mathrm{C}$ (between $-24 \%$ and $-29 \%$ ), ruling out the possibility of a large contribution of $\mathrm{CO}_{2}$ from carbonate dissolution. Furthermore, the ${ }^{14} \mathrm{C}$ contents of the samples from the background wells that were not impacted by the high- ${ }^{14} \mathrm{C} \mathrm{CO}_{2}$ were close to atmospheric concentrations, implying that dissolution of carbonates is not a significant source of subsurface $\mathrm{CO}_{2}$.

Of the organic contaminants at the site, the lubricating oils represent a more likely source for the $\mathrm{CO}_{2}$ than the chlorinated solvents. The $\delta^{13} \mathrm{C}$ values of the $\mathrm{CO}_{2}$ are in the appropriate range for oil $(-24 \%$ to $-32 \%$; Schoell, 1984$)$ but are on the high side for chlorinated solvents. $\delta^{13} \mathrm{C}$ values reported in the literature for the chlorinated solvents range from $-33 \%$ to $-47 \%$ for carbon tetrachloride, $-23 \%$ to $-37 \%$ for perchloroethene, $-28 \%$ to $-43 \%$ for trichloroethene, and $-26 \%$ o to $-32 \%$ for 1,1,1-trichloroethane (van Warmerdam et al., 1995; Holt et al., 1997; Beneteau et al., 1999; Hunkeler and Aravena, 2000; Jendrzejewski et al., 2001). Furthermore, the stable carbon isotope ratios of two samples of bulk chlorinated solvents in gas samples collected from the RWMC were trapped onto resin columns and analyzed, giving $\delta^{13} \mathrm{C}$ values of $-32 \%$ and $-38 \%$. It is possible that there was preferential degradation of higher $\delta^{13} \mathrm{C}$ solvents (e.g., perchloroethene), but it is unlikely that a significant amount of the $\mathrm{CO}_{2}$ in the SDA was derived from breakdown of the solvents. 


\section{Estimated Rate of Biodegradation of Oils}

The rate of degradation of the lubricating oils translates to a rate of production of $\mathrm{CO}_{2}$ in the subsurface, which can be estimated roughly from the elevated $\mathrm{CO}_{2}$ concentrations in the pore gas. We derive this estimate from a simplified model of the $\mathrm{CO}_{2}$ production and transport in the region under the $0.7 \%$ contour shown in Figure 3a. We assume that $\mathrm{CO}_{2}$ is being produced in a volume of rock that has the areal dimensions of the $0.7 \%$ contour (area $\approx 75000 \mathrm{~m}^{2}$ ) and a vertical dimension corresponding to the depth interval 10 to $30 \mathrm{~m}$ below the ground surface. The total volume of producing rock is then $1.5 \times 10^{6} \mathrm{~m}^{3}$. The $\mathrm{CO}_{2}$ produced in this volume of rock must diffuse out through the pore space, and over a period of time the $\mathrm{CO}_{2}$ concentration may reach a steady state concentration that reflects the balance between production and loss by diffusion into the surrounding low- $\mathrm{CO}_{2}$ pore air. If the producing volume of rock is modeled as a 1-dimensional system, which is reasonable insofar as the lateral dimensions are much greater than the vertical, then the steady state maximum $\mathrm{CO}_{2}$ concentration is given by:

$$
\left[\mathrm{CO}_{2}\right]_{\max }=\left[\mathrm{CO}_{2}\right]_{a m b}+\frac{G_{\mathrm{CO}_{2}} a}{D_{\mathrm{CO}_{2}} \phi \tau}\left(d-\frac{a}{2}\right)
$$

Where the brackets represent concentrations of $\mathrm{CO}_{2}$ in pore air, $G_{\mathrm{CO} 2}$ is the production rate of $\mathrm{CO}_{2}$ per unit volume of soil, $a$ is the half-thickness of the $\mathrm{CO}_{2}$ producing layer in the subsurface, $d$ is the depth to the middle of the producing layer, $D_{\mathrm{CO} 2}$ is the diffusivity of $\mathrm{CO}_{2}$ in air, and $\phi$ and $\tau$ are porosity and tortuosity. Rearranging this equation, we can express the total production of $\mathrm{CO}_{2}$ as: 


$$
P_{\text {total }}=2 A_{\text {prod }} \frac{D_{\mathrm{CO}_{2}} \phi \tau}{(d-a / 2)}\left(\left[\mathrm{CO}_{2}\right]_{\max }-\left[\mathrm{CO}_{2}\right]_{\text {amb }}\right)
$$

This equation applies to a layer of thickness $2 a$ at depth $d$, with $\mathrm{CO}_{2}$ concentration held at the ambient value at the top and bottom boundaries, uniform $\mathrm{CO}_{2}$ production within the layer, and transport only by diffusion through the pore space (porosity, $\phi \approx 0.1$ ) in the vertical direction. Substituting the values $D_{\mathrm{CO} 2}=756 \mathrm{~m}^{2} / \mathrm{yr}, \phi=0.1, \tau=0.5, a=10 \mathrm{~m}, \mathrm{~d}=20 \mathrm{~m}, 0.011$ and 0.002 as the maximum and ambient $\mathrm{CO}_{2}$ concentrations $\left(\mathrm{m}^{3} / \mathrm{m}^{3}\right.$ air $)$, and the estimated area $\left(A_{\text {prod }}=\right.$ $75,000 \mathrm{~m}^{2}$ ), the resultant value is about $3400 \mathrm{~m}^{3} \mathrm{CO}_{2}$ per year. This corresponds to the conversion of 1.7 metric tons of carbon to $\mathrm{CO}_{2}$ per year. The concentrations predicted by the model are plotted versus depth with the data on Fig. 8. These calculations are also consistent with the lower $\delta^{13} \mathrm{C}$ values for $\mathrm{CO}_{2}$ observed within the SDA.

The simplicity of our model makes this estimate very rough. The actual value could be anywhere from about 0.5 to 3 tons $\mathrm{C} / \mathrm{yr}$. Decreasing the concentration gradients at the upper and lower boundaries of the layer would lower the estimated production. Higher estimates would result if lateral transport were accounted for, as well as $\mathrm{CO}_{2}$ production from rock outside of the core volume used for the calculation.

\section{Significance of Findings}

The primary goal of this project was to evaluate the levels of intrinsic bioremediation of organic contaminants in the burial pits at the RWMC. The $\mathrm{CO}_{2}$ concentrations in the subsurface around the burial pits were elevated by 3 - to 5 -fold relative to background. The stable carbon 
isotope ratios of the $\mathrm{CO}_{2}$ indicate a source with $\delta^{13} \mathrm{C}$ values between $-21 \%$ and $-28 \%$ and the low ${ }^{14} \mathrm{C}$ contents of several samples confirm that the $\mathrm{CO}_{2}$ is mainly derived from aerobic biodegradation of fossil hydrocarbons, with the primary source being the lubricating oils and not the chlorinated solvents. The high $\mathrm{O}_{2}$ content of the pore gas $(>18 \%)$ and the existence of a subsurface bacterial community at the RWMC dominated by strict aerobes (Colwell, 1989) supports this conclusion.

The $\mathrm{CO}_{2}$ anomaly corresponds to a biodegradation rate for the lubricating oils of 1 metric ton of carbon per year. The total amount of lubricating oil in the subsurface at the SDA is estimated at 125 metric tons (Anderson and Lewis, 1989). Assuming that the oils are $80 \%$ carbon by weight, approximately 100 metric tons of carbon in the form of lubricating oils was buried at the site. If all of the oil has leaked out of the containers and is available to be degraded (which is highly unlikely), this suggests an approximate intrinsic biodegradation rate for the oils of $1-2 \%$ per year.

The estimated biodegradation rate for the lubricating oils is low relative to rates estimated at other sites. For a production volume of $1.5 \times 10^{6} \mathrm{~m}^{3}$ of rock, the degradation rate is $1.15 \mathrm{~g} \mathrm{C} / \mathrm{cm}^{3}$ per year. By comparison, Baker et al. (2000) measured biodegradation rates for BTEX compounds and gasoline in soil of hundreds to thousands of $\mathrm{g} / \mathrm{cm}^{3}$ per year. However, lubricating oils tend to have very low vapor pressures and it is probable that the biological activity within the production zone is limited to areas within close proximity to the oils. Given that the RWMC production zone is hosted in fractured basalts, the distribution of the oils within this zone is undoubtedly highly heterogeneous. Therefore, the actual volume of the rock in which active biodegradation of the oils is occurring could easily be $<1 \%$ of our production zone. 
The results of this study also have significant implications for gas transport in the vadose zone at the RWMC. Elevated ${ }^{14} \mathrm{C}-\mathrm{CO}_{2}$ was detected in samples at distances of greater than $1 \mathrm{~km}$ from the suspected source. However, the impact of the vapor extraction units on $\mathrm{CO}_{2}$ concentrations appears to be limited to less than $100 \mathrm{~m}$. This suggests that advective gas transport is limited to local fracture networks and large-scale transport through the rock matrix is diffusion-limited.

\section{ACKNOWLEDGMENTS}

Eric Miller of the INEEL was instrumental in arranging the field-sampling program for this project. Assistance with sample collection by Larry Lazzarotto and Donald Song is greatly appreciated. Help with sample analyses by Donald Song and Alexis Templeton is also gratefully acknowledged. Michael Singleton provided helpful suggestions to improve this manuscript. Support for this work was provided by the Assistant Secretary for Environmental Management, Office of Science and Technology, under the Environmental Management Science Program of the U.S. Department of Energy under Contract No. DE-AC03-76SF00098.

\section{REFERENCES}

Aelion, C.M., B.C. Kirtland, and P.A. Stone. 1997. Radiocarbon assessment of aerobic petroleum bioremediation in the vadose zone and groundwater at an AS/SVE site. Environ. Sci. Tech. 31:3363-3370.

Aggarwal, P.K., and R.E. Hinchee. 1991. Monitoring in situ biodegradation of hydrocarbons using stable carbon isotopes. Environ. Sci. Tech. 25:1178-1180. 
Anderson, S.R., and B.D. Lewis. 1989. Stratigraphy of the unsaturated zone at the Radioactive Waste Management Complex, Idaho National Engineering Laboratory, Idaho. WaterResources Investigations Report 89-4065. U.S. Geol. Survey, Idaho Falls, Idaho.

Baker, R.J., A.L. Baehr, and M.A. Lahvis. 2000. Estimation of hydrocarbon biodegradation rates in gasoline-contaminated sediment from measured respiration rates. J. Contaminant Hydrol. 41:175-192.

Beneteau, K.M., R. Aravena, and S.K. Frape. 1999. Isotopic characterization of chlorinated solvents - laboratory and field results. Organic Geochem. 30:739-753.

Cerling, T.E. 1984. The stable isotopic composition of modern soil carbonate and its relationship to climate. Earth and Plan. Sci. Letters 71:229-240.

Colwell, F.S. 1989. Microbiological comparison of surface soil and unsaturated subsurface soil from a semiarid high desert. App. Environ. Microbiol. 55:2420-2423.

Conrad, M.E., P.F. Daley, M.F. Fischer, B.B. Buchanan, T. Leighton, and M. Kashgarian. 1997. Combined ${ }^{14} \mathrm{C}$ and $\delta^{13} \mathrm{C}$ monitoring of in situ biodegradation of petroleum hydrocarbons. Environ. Sci. Tech. 31:1463-1469.

Conrad, M.E., A.S. Templeton, P.F. Daley, and L. Alvarez-Cohen. 1999. Isotopic evidence for biological controls on migration of petroleum hydrocarbons. Organic Geochem. 30:843-859.

Holt, B.D., N.C. Sturchio, T.A. Abrajano, and T.A. Heraty. 1997. Conversion of chlorinated volatile organic compounds to carbon dioxide and methyl chloride for isotopic analysis of carbon and chlorine. Anal. Chem. 69: 2727-2733.

Hunkeler, D., and R. Aravena. 2000. Determination of compound-specific carbon isotope ratios of chlorinated methanes, ethanes, and ethenes in aqueous samples. Environ. Sci. Tech. 34:2839-2844. 
Jendrzejewski, N., H.G.M. Eggenkamp, and M.L. Coleman. 2001. Characterisation of chlorinated hydrocarbons from chlorine and carbon isotopic compositions: scope of application to environmental problems. App. Geochem. 16:1021-1031.

Landmeyer, J.E., D.A. Vroblesky, and F.H. Chapelle. 1996. Stable carbon isotope evidence of biodegradation zonation in a shallow jet-fuel contaminated aquifer. Environ. Sci. Tech. 30:1120-1128.

Lloyd, D.H., J.S.Vogel, and S. Trumbore. 1991. Lithium contamination in AMS measurements of ${ }^{14} \mathrm{C}$. Radiocarbon 33:297-301.

Ostendorf, D.W., and D.H. Kampbell. 1991. Biodegradation of hydrocarbon vapors in the unsaturated zone. Water Resour. Res. 27:453-462.

Parsons Engineering Sciences. 1995. Radioactive Waste Management Complex organic contamination in the vadose zone well installation: Operable unit 7-08. Well Completion Rep. Parsons Engineering Sciences, Inc., RD/RA Services, Idaho Falls, Idaho.

Revesz, K., T.B. Coplen, M.J. Baedecker, and P.D. Glynn. 1995. Methane production and consumption monitored by stable $\mathrm{H}$ and $\mathrm{C}$ isotope ratios at a crude oil spill site, Bemidji, Minnesota. App. Geochem. 10:505-516.

Rice, D.W., B.P. Dooher, S.J. Cullen, L.G. Everett, W.E. Kastenberg, R.D. Grose, and M.A. Marino. 1995. Recommendation to Improve the Cleanup Process for California's Leaking Underground Fuel Tanks (LUFTs). Lawrence Livermore National Laboratory, Livermore, CA (UCRL-AR-12176).

Ritter, P.D., and D.L. McElroy. 1999. Progress Report: Tritium and Carbon-14 Sampling at the Radioactive Waste Management Complex. Lockheed Martin Idaho Technologies Company (INEEL-98-00669). 
Schoell, M. 1984. Stable isotopes in petroleum research. Advances in Petroleum Geochem. 1, p. 215-245.

Suchomel, K.H., D.K. Kreamer, and A. Long. 1990. Production and transport of carbon dioxide in a contaminated vadose zone: a stable and radioactive carbon isotope study. Environ. Sci. Tech. 24:1824-1831.

Tobin, K.J., T.C. Onstott, and F. Colwell. 1997. Establishing background calcite mineralization as a prelude to an in situ bioremediation effort (INEL, Idaho). Geol. Soc. Am., Abst. with Prog. 26, no. 6:A153.

van Warmerdam, E.M., S.K. Frape, R. Aravena, R.J. Drimmie, H. Flatt, and J.A. Cherry. 1995. Stable chlorine and carbon isotope measurements of selected chlorinated organic solvents. App. Geochem. 10:547-552.

Wiedemeier, T.H., H.S. Rifai, C.J.Newell, and J.T.Wilson. 1999. Natural Attenuation of Fuels and Chlorinated Solvents; John Wiley and Sons Inc., U.S.A.

Wigley, T.M.L., L.N. Plummer, and F.J. Pearson, Jr. 1978. Mass transfer and carbon isotope evolution in natural water systems. Geochim. et Cosmochim. Acta 42:1117-1139.

\section{Figure Captions}

Fig. 1. Map of the RWMC site showing the location of the wells sampled for this study. Also plotted are the locations of the waste disposal pits, the soil vault containing the beryllium reactor blocks, the vapor extraction units, and the A-A' longitudinal cross section in Fig. 4. The inset shows the location of the RWMC within the INEEL and the state of Idaho. 
Fig. 2. $\mathrm{CO}_{2}$ concentrations and $\delta^{13} \mathrm{C}$ values versus depth for samples from the SDA and from background wells. The main depth interval of elevated concentrations is between $10 \mathrm{~m}$ and $30 \mathrm{~m}$ (shown shaded). Slightly elevated values occur down to $75 \mathrm{~m}$ depth. Soils from the TEM1 locality and from farther to the west of that locality have particularly high $\mathrm{CO}_{2}$ values within a few meters of the surface. These values require very high local production rates of $\mathrm{CO}_{2}$ (from root respiration).

Fig. 3. Average $\mathrm{CO}_{2}$ concentrations (in volume \%) in pore gas samples collected from different depth intervals in and around the RWMC site.

Fig. 4. Longitudinal cross section A-A' (Fig. 1) passing through the high $\mathrm{CO}_{2}$ zone in the RWMC with contours of the labeled average $\mathrm{CO}_{2}$ concentrations measured for pore gas samples collected from different sampling port in wells within $100 \mathrm{~m}$ of the section. The approximate extent of the surficial sediments and the sedimentary interbeds are shown as shaded areas on the section.

Fig. 5. $\mathrm{CO}_{2}$ concentrations measured over time in three vapor sampling ports in borehole 8801 , showing the effect of vapor extraction from borehole 8901 (located approximately $20 \mathrm{~m}$ from 8801). Dashed lines indicate intervals where a sampling period was missed.

Fig. 6. Inverse concentrations of $\mathrm{CO}_{2}$ in pore gas samples from between 10 and $70 \mathrm{~m}$ depth in the high- $\mathrm{CO}_{2}$ zone in the SDA. Allowing for a shift of $4.4 \%$ for diffusive fractionation 
(Cerling, 1984), this data suggests that the source for the increased $\mathrm{CO}_{2}$ in the vicinity of the disposal pits of has a $\delta^{13} \mathrm{C}$ value of between -24 and $-29 \%$.

Fig. 7. Radiocarbon contents (in fraction of modern atmospheric carbon) in $\mathrm{CO}_{2}$ samples collected for this study. Values in parentheses indicate the depth at which the sample was collected.

Fig. 8. Comparison of model results for $\mathrm{a}=10 \mathrm{~m}$ and $\mathrm{d}=20 \mathrm{~m}$ and measured $\mathrm{CO}_{2}$ concentrations versus depth. This model uses a specific $\mathrm{CO}_{2}$ production rate of $0.0023 \mathrm{~m}^{3}$ $\mathrm{CO}_{2} / \mathrm{m}^{3}$ rock per year in the producing layer between 10 and $30 \mathrm{~m}$ depth (shown shaded) and gives a total $\mathrm{CO}_{2}$ production for a $150 \mathrm{~m} \times 500 \mathrm{~m}$ area equivalent to the degradation of approximately 1.7 metric tons of carbon per year. 


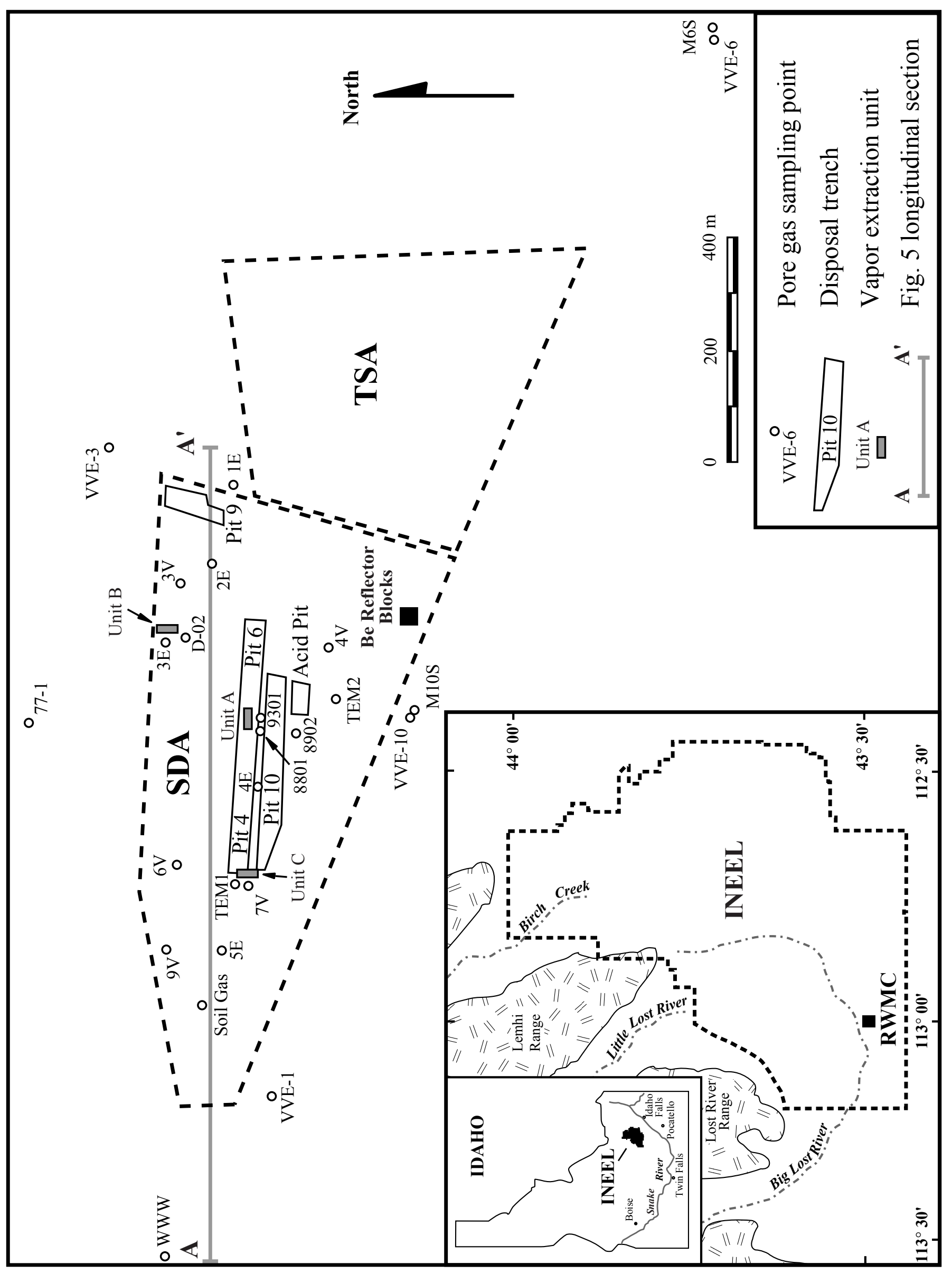



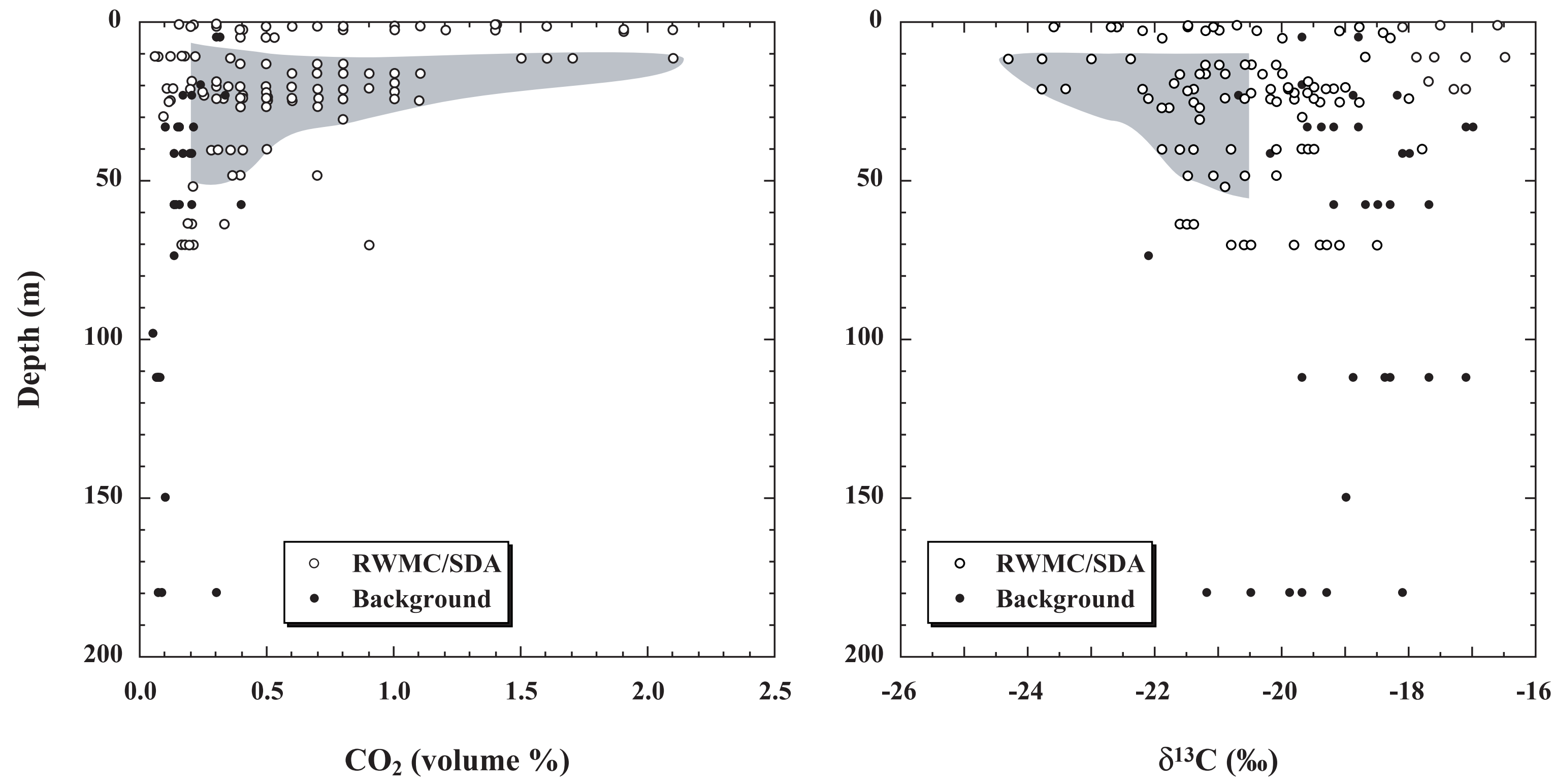

Figure 2 


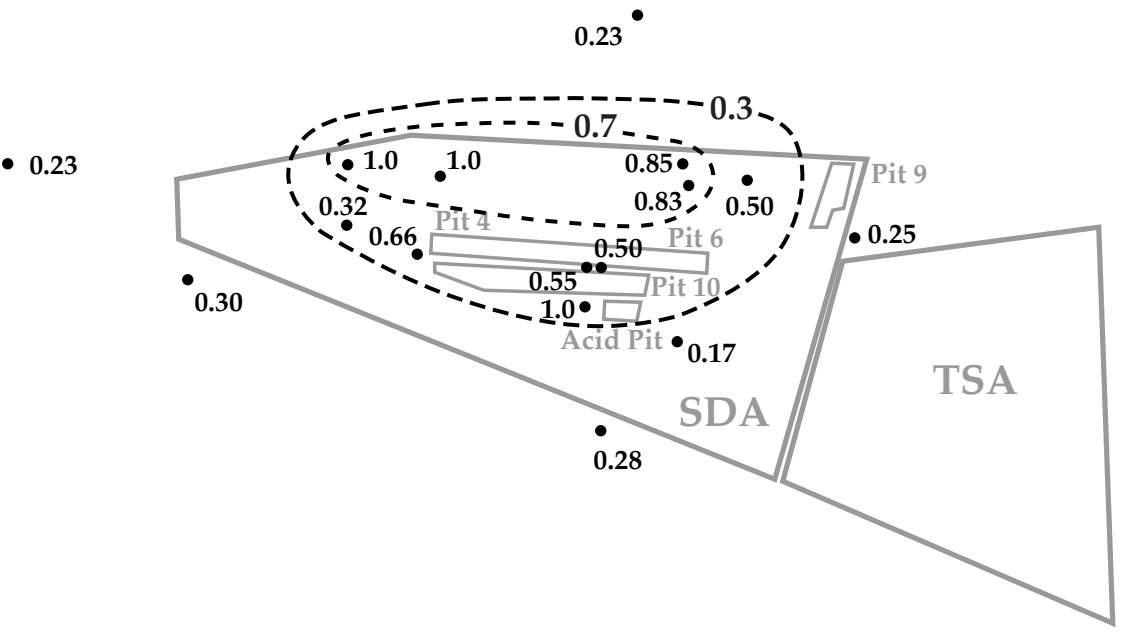

a) $\mathbf{1 0 - 2 5} \mathrm{m}$ depth
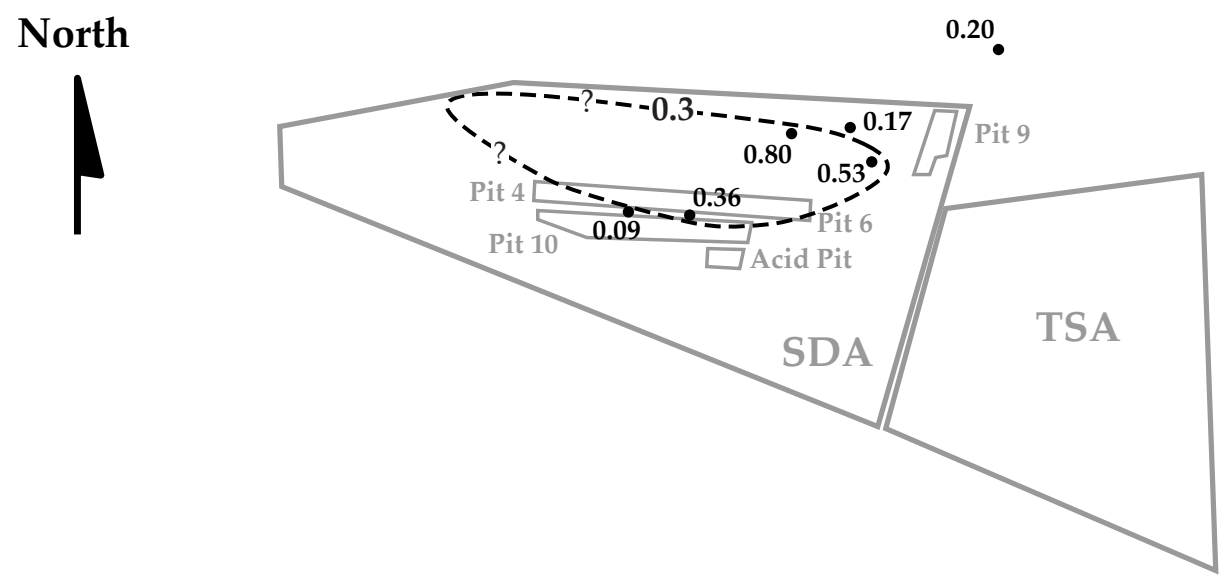

b) $25-40 \mathrm{~m}$ depth

- 0.17

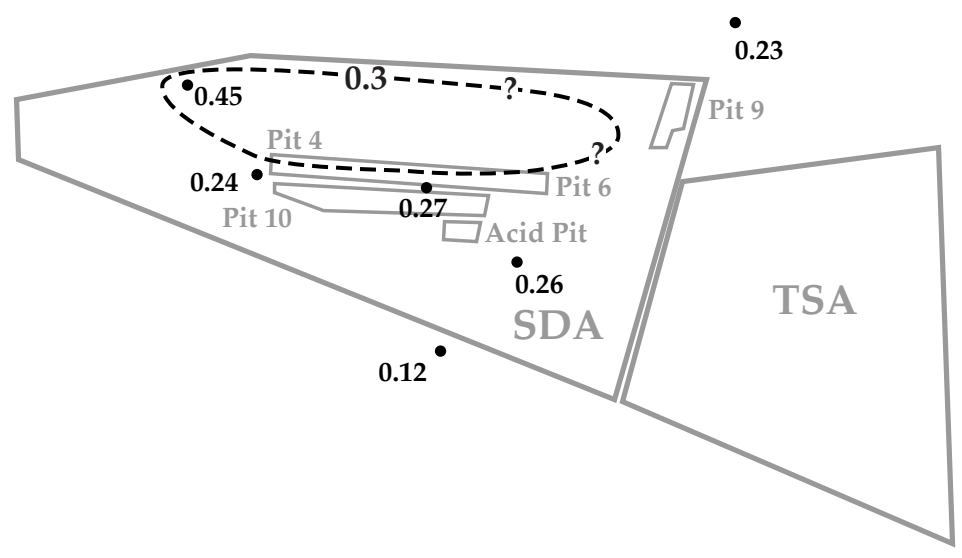

c) $40-70 \mathrm{~m}$ depth

$0 \quad 400 \mathrm{~m}$

-.44 Sampling point with average $\% \mathrm{CO}_{2}$ for interval

\section{Figure 3}




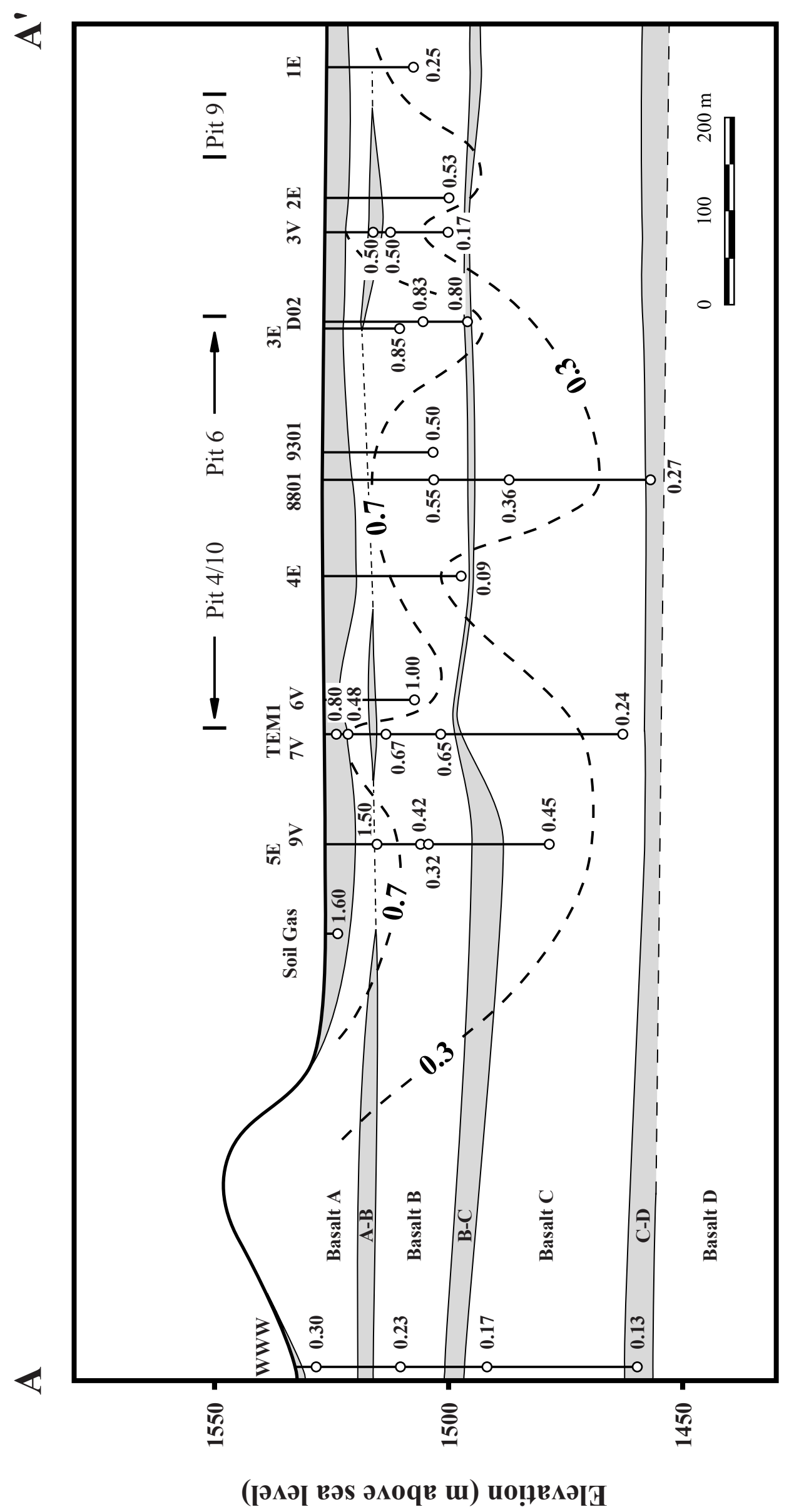

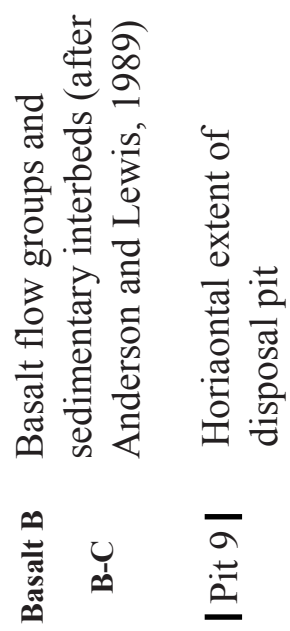
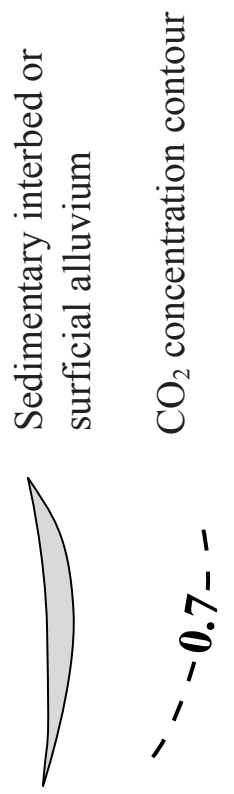

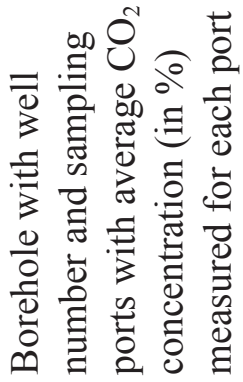

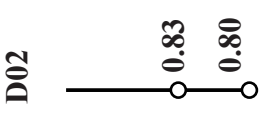




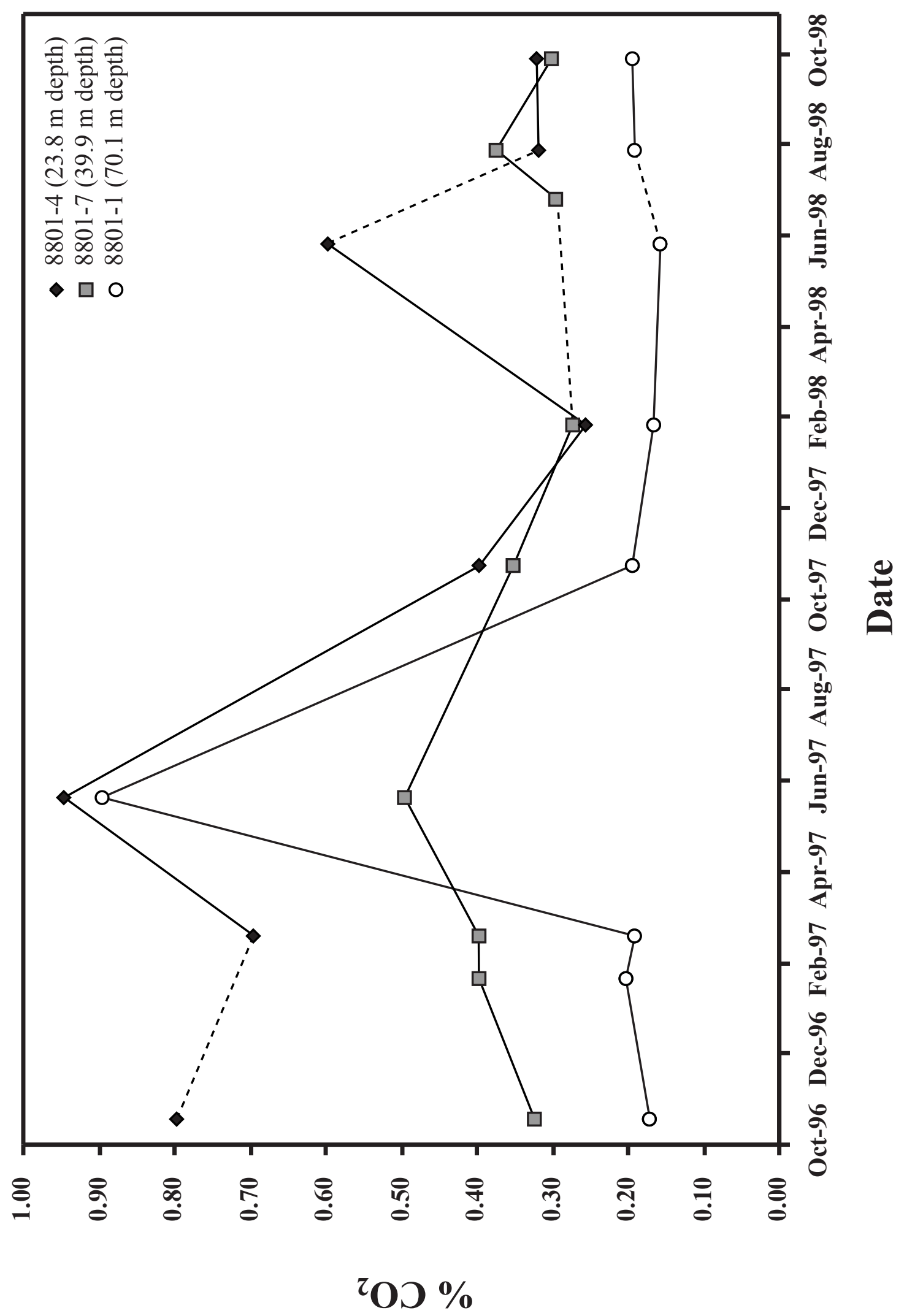




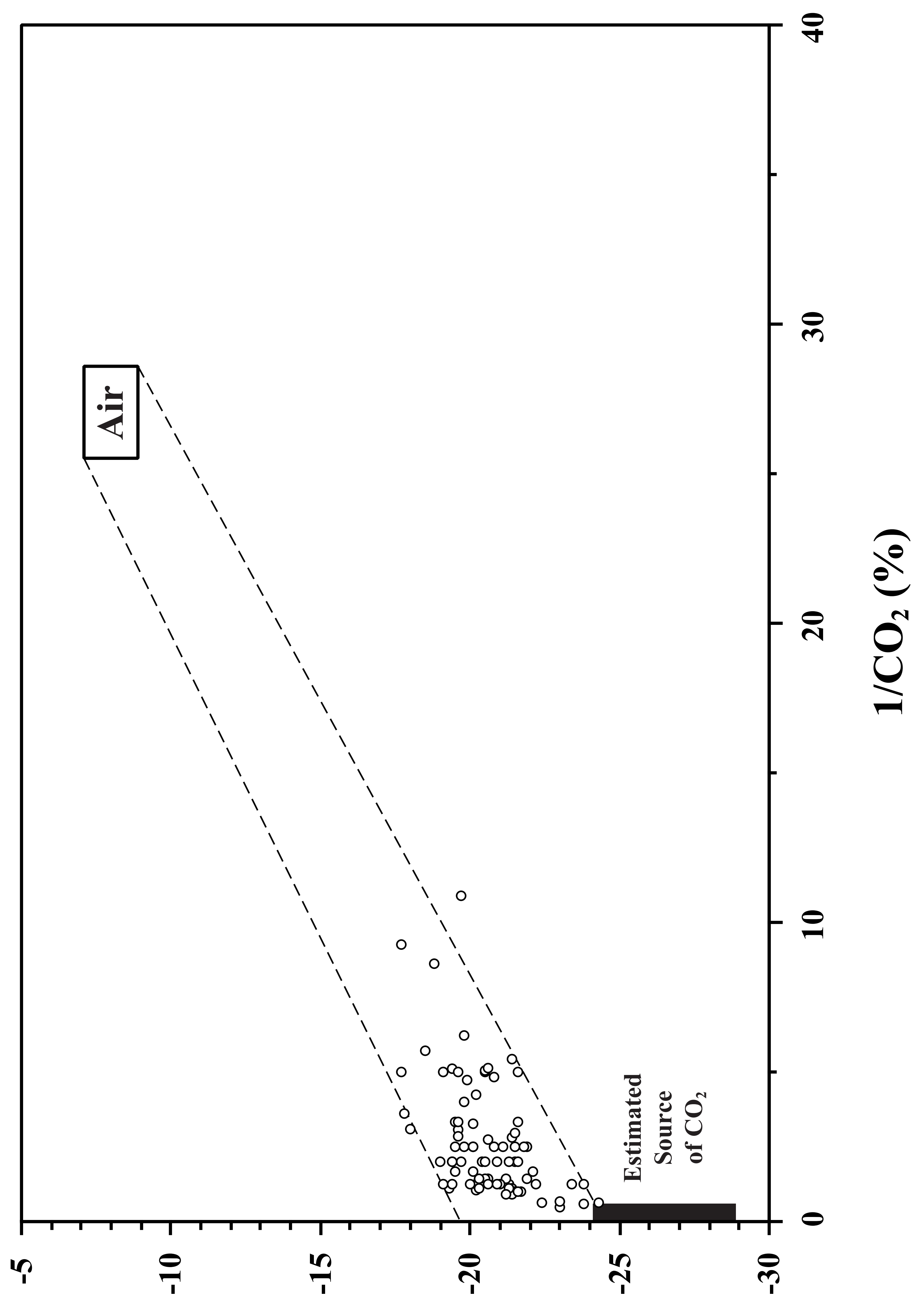

(\%\%) $\mathcal{D}_{\mathcal{E} I} \subseteq$ 


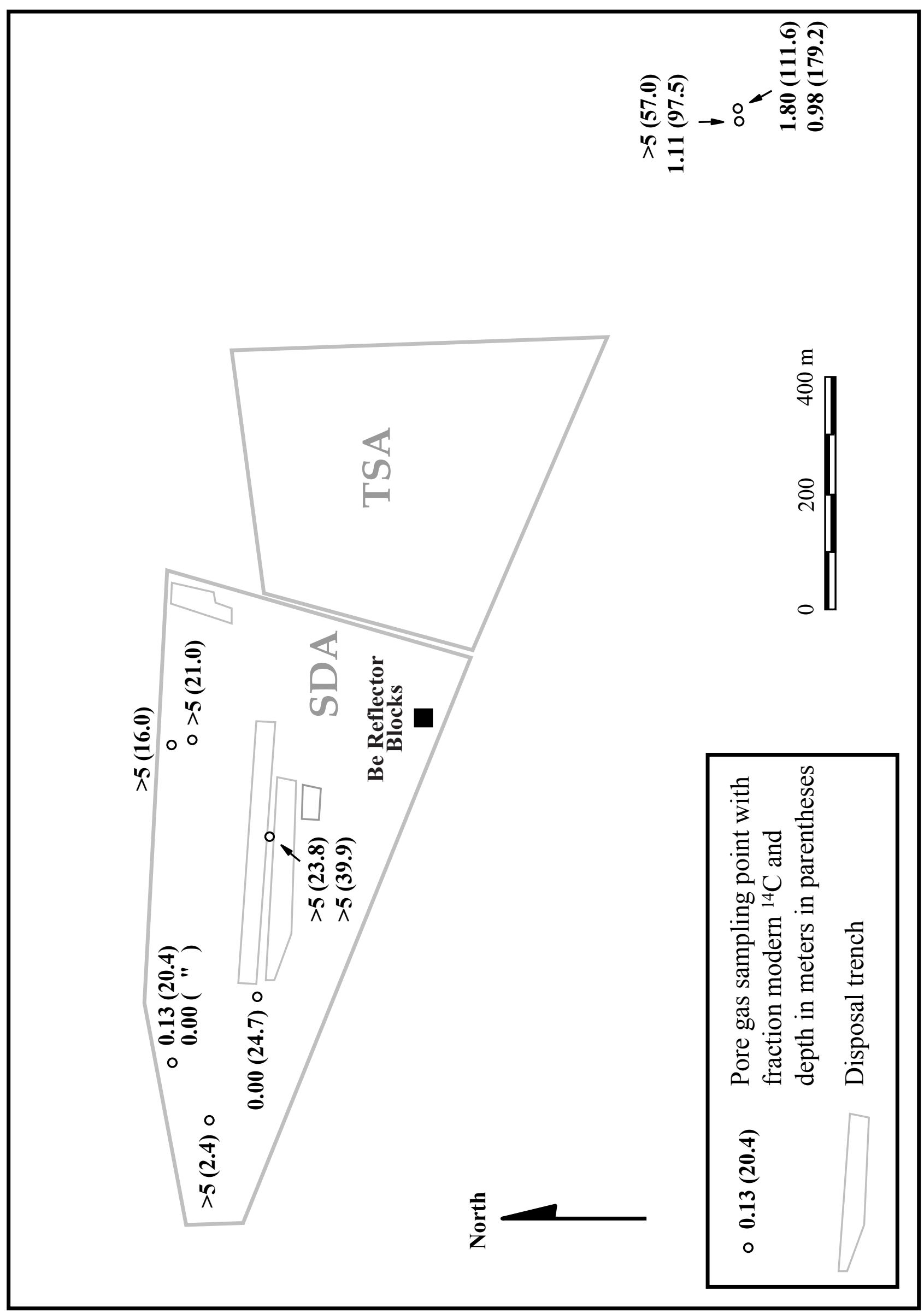




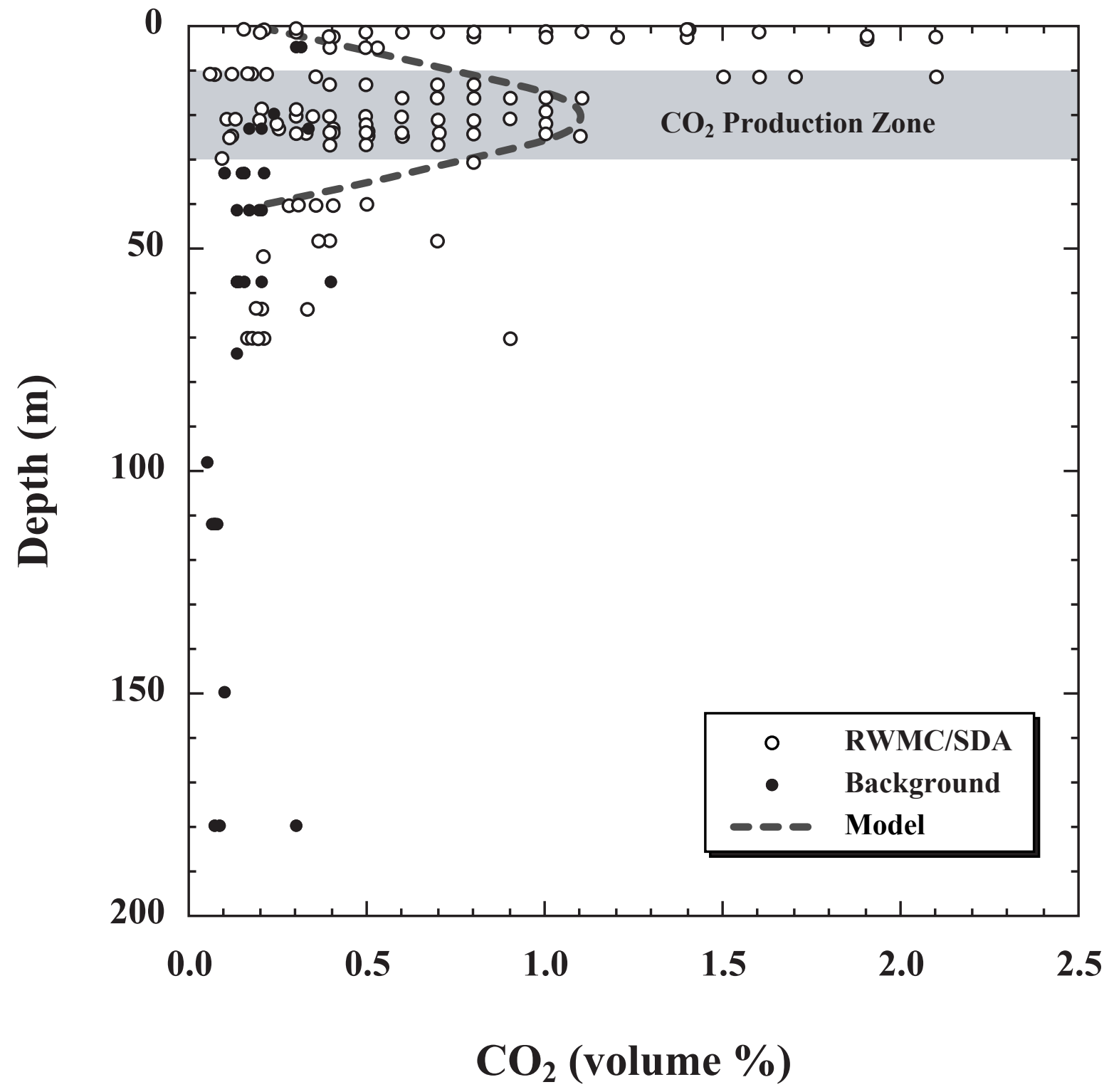

Figure 8 
Table 1. $\mathrm{CO}_{2}$ concentrations and isotopic compositions of samples collected for this study.

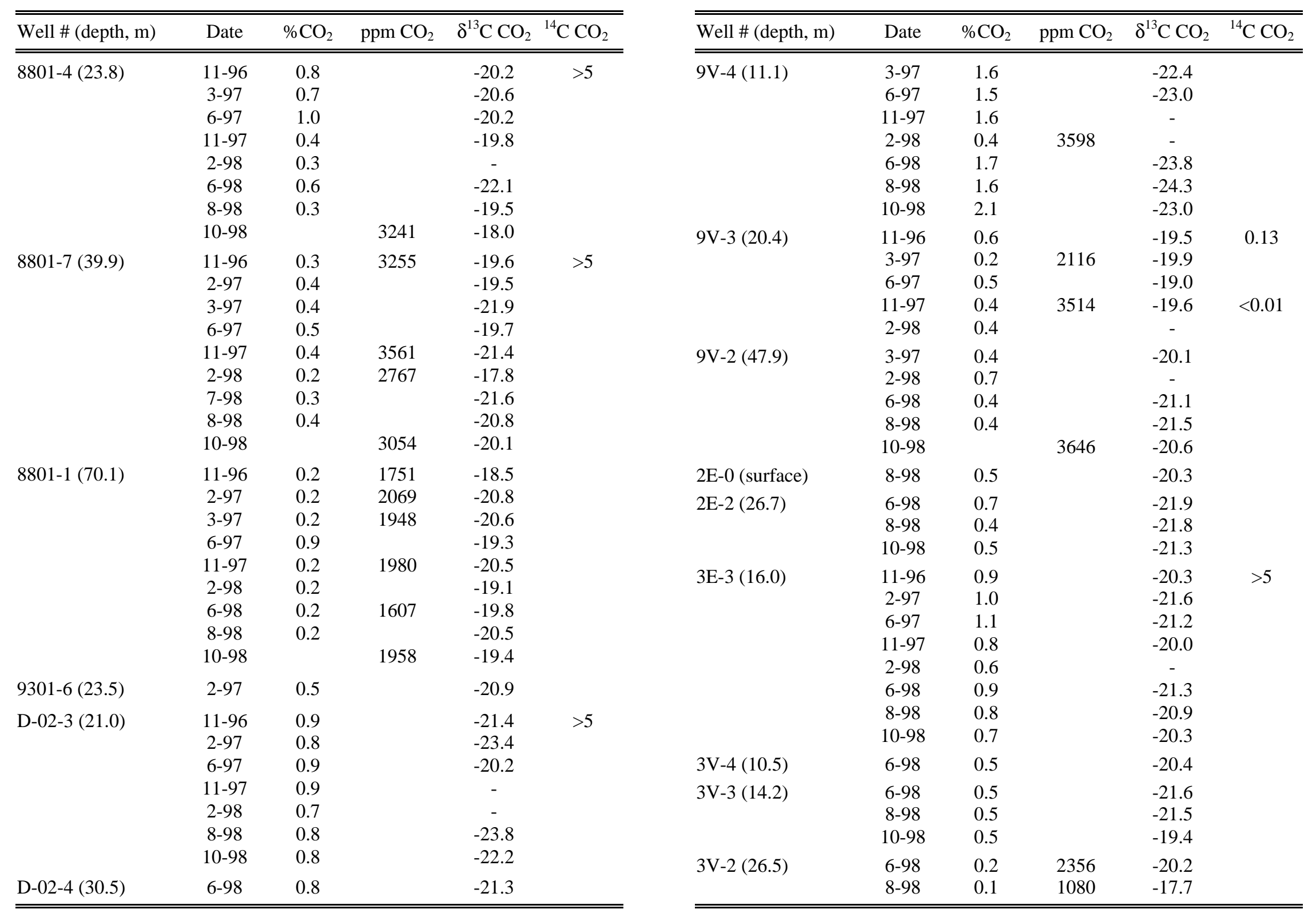




\begin{tabular}{|c|c|c|c|c|c|}
\hline Well \# (depth, m) & Date & $\% \mathrm{CO}_{2}$ & ppm $\mathrm{CO}_{2}$ & $\delta^{13} \mathrm{C} \mathrm{CO}_{2}$ & ${ }^{14} \mathrm{C} \mathrm{CO}_{2}$ \\
\hline Soil Gas 30 (0.6) & $\begin{array}{c}3-97 \\
11-97 \\
2-98 \\
6-98 \\
8-98\end{array}$ & $\begin{array}{l}0.0 \\
0.0 \\
0.2 \\
0.1\end{array}$ & $\begin{array}{c}516 \\
1581 \\
503 \\
873\end{array}$ & $\begin{array}{l}-12.5 \\
-17.1 \\
-17.5 \\
-11.4 \\
-12.3\end{array}$ & \\
\hline Soil Gas 31 (1.2) & $\begin{array}{c}3-97 \\
11-97 \\
2-98 \\
6-98 \\
8-98\end{array}$ & $\begin{array}{l}0.7 \\
0.2 \\
0.3 \\
1.1 \\
0.2\end{array}$ & & $\begin{array}{c}-21.1 \\
-18.8 \\
- \\
-18.1 \\
-\end{array}$ & \\
\hline Soil Gas 32 (2.4) & $\begin{array}{c}3-97 \\
11-97 \\
2-98 \\
6-98\end{array}$ & $\begin{array}{l}1.9 \\
1.4 \\
1.0 \\
2.1\end{array}$ & & $\begin{array}{c}-21.2 \\
-19.1 \\
- \\
-20.4\end{array}$ & $>5$ \\
\hline TEM1-4 (1.2) & $\begin{array}{c}11-97 \\
2-98 \\
6-98 \\
8-98 \\
10-98\end{array}$ & $\begin{array}{l}1.0 \\
0.5 \\
0.3 \\
1.6 \\
1.1\end{array}$ & & $\begin{array}{l}-18.8 \\
-21.5 \\
-22.7 \\
-22.6\end{array}$ & \\
\hline TEM1-8 (2.4) & $\begin{array}{c}11-97 \\
2-98 \\
8-98\end{array}$ & $\begin{array}{l}0.8 \\
0.4 \\
1.2\end{array}$ & & $\begin{array}{c}-21.0 \\
- \\
-22.2\end{array}$ & \\
\hline TEM1-16 (4.9) & $\begin{array}{c}11-97 \\
2-98 \\
8-98 \\
10-98\end{array}$ & $\begin{array}{l}0.5 \\
0.5 \\
0.4 \\
0.5\end{array}$ & 5291 & $\begin{array}{c}-18.3 \\
- \\
-21.9 \\
-20.0\end{array}$ & \\
\hline 5E-1 (22.1) & $\begin{array}{c}6-98 \\
8-98 \\
10-98\end{array}$ & $\begin{array}{l}0.5 \\
0.2\end{array}$ & 2498 & $\begin{array}{l}-20.5 \\
-19.6 \\
-19.8\end{array}$ & \\
\hline $4 V-3(20.7)$ & $\begin{array}{c}6-97 \\
11-97 \\
2-98 \\
6-98 \\
8-98 \\
10-98\end{array}$ & $\begin{array}{l}0.3 \\
0.1 \\
0.0 \\
0.3 \\
0.2\end{array}$ & $\begin{array}{l}1115 \\
1074 \\
1314\end{array}$ & $\begin{array}{l}-19.2 \\
-15.2 \\
-17.3 \\
-19.9 \\
-19.3 \\
-17.1\end{array}$ & \\
\hline $4 \mathrm{~V}-2(51.4)$ & $\begin{array}{c}2-98 \\
10-98\end{array}$ & 0.2 & $\begin{array}{l}2078 \\
3111\end{array}$ & $\begin{array}{c}-20.9 \\
-\end{array}$ & \\
\hline
\end{tabular}

\begin{tabular}{|c|c|c|c|c|c|}
\hline Well \# (depth, m) & Date & $\% \mathrm{CO}_{2}$ & ppm $\mathrm{CO}_{2}$ & $\delta^{13} \mathrm{C} \mathrm{CO}_{2}$ & ${ }^{14} \mathrm{C} \mathrm{CO}_{2}$ \\
\hline TEM2-2 (0.6) & $\begin{array}{c}11-97 \\
2-98 \\
7-98\end{array}$ & $\begin{array}{l}0.3 \\
0.2 \\
1.4\end{array}$ & 2114 & $\begin{array}{l}-20.7 \\
-16.6 \\
-21.5\end{array}$ & \\
\hline TEM2-4 (1.2) & $\begin{array}{c}11-97 \\
2-98 \\
7-98\end{array}$ & $\begin{array}{l}0.6 \\
0.3 \\
0.8\end{array}$ & & $\begin{array}{c}-18.8 \\
- \\
-23.6\end{array}$ & \\
\hline TEM2-8 (2.4) & $\begin{array}{c}11-97 \\
2-98 \\
7-98\end{array}$ & $\begin{array}{l}2.1 \\
1.2 \\
0.4\end{array}$ & & $\begin{array}{c}-21.0 \\
- \\
-22.2\end{array}$ & \\
\hline TEM2-10 (3.0) & $11-97$ & 1.9 & & -18.4 & \\
\hline $7 \mathrm{~V}-4(13.0)$ & $\begin{array}{c}3-97 \\
6-97 \\
11-97 \\
2-98 \\
6-98 \\
8-98 \\
10-98\end{array}$ & $\begin{array}{l}0.8 \\
0.8 \\
0.7 \\
0.8 \\
0.7 \\
0.4 \\
0.5\end{array}$ & & $\begin{array}{c}-21.0 \\
-20.6 \\
-20.5 \\
- \\
-21.2 \\
-20.1 \\
-\end{array}$ & \\
\hline $7 \mathrm{~V}-3(24.7)$ & $\begin{array}{c}2-97 \\
3-97 \\
11-97 \\
2-98 \\
7-98 \\
8-98 \\
10-98\end{array}$ & $\begin{array}{l}1.1 \\
0.8 \\
0.8 \\
0.6 \\
0.1 \\
0.5 \\
0.6\end{array}$ & 1160 & $\begin{array}{c}-21.4 \\
-19.4 \\
-19.1 \\
- \\
-18.8 \\
-19.4 \\
-20.1\end{array}$ & $<0.01$ \\
\hline $7 \mathrm{~V}-1(63.6)$ & $\begin{array}{c}11-97 \\
6-98 \\
8-98\end{array}$ & $\begin{array}{l}0.3 \\
0.2 \\
0.2\end{array}$ & $\begin{array}{l}3374 \\
1842\end{array}$ & $\begin{array}{l}-21.5 \\
-21.4 \\
-21.6\end{array}$ & \\
\hline $6 \mathrm{~V}-4(19.1)$ & $2-97$ & 1.0 & & -21.7 & \\
\hline $8902-6(21.6)$ & $2-97$ & 1.0 & & -21.5 & \\
\hline 4E-1 (29.4) & $7-98$ & 0.0 & 918 & -19.7 & \\
\hline $4 \mathrm{~V}-4(10.5)$ & $\begin{array}{c}6-97 \\
11-97 \\
6-98 \\
8-98 \\
10-98\end{array}$ & $\begin{array}{l}0.2 \\
0.2 \\
0.1\end{array}$ & $\begin{array}{c}1632 \\
2140 \\
661 \\
1180 \\
1729\end{array}$ & $\begin{array}{l}-18.7 \\
-17.9 \\
-16.5 \\
-17.1 \\
-17.6\end{array}$ & \\
\hline
\end{tabular}




\begin{tabular}{|c|c|c|c|c|}
\hline Well \# (depth, m) & Date & $\% \mathrm{CO}_{2}$ & ppm $\mathrm{CO}_{2}$ & $\delta^{13} \mathrm{C} \mathrm{CO}_{2}{ }^{14} \mathrm{C} \mathrm{CO}_{2}$ \\
\hline WWW-7 (4.6) & $\begin{array}{c}8-98 \\
10-98\end{array}$ & 0.3 & 3127 & $\begin{array}{l}-19.7 \\
-18.8\end{array}$ \\
\hline WWW-5 (22.6) & $\begin{array}{c}6-98 \\
7-98 \\
8-98 \\
10-98\end{array}$ & $\begin{array}{l}0.2 \\
0.2 \\
0.2\end{array}$ & $\begin{array}{l}1650 \\
3358\end{array}$ & $\begin{array}{l}-18.9 \\
-20.7 \\
-12.1 \\
-18.2\end{array}$ \\
\hline WWW-3 (41.1) & $\begin{array}{c}6-98 \\
7-98 \\
8-98 \\
10-98\end{array}$ & $\begin{array}{l}0.2 \\
0.2\end{array}$ & $\begin{array}{l}1291 \\
1938 \\
1676\end{array}$ & $\begin{array}{l}-18.1 \\
-20.2 \\
-18.0 \\
-18.0\end{array}$ \\
\hline WWW-1 (73.2) & $7-98$ & 0.1 & 1309 & -22.1 \\
\hline VVE-10-3 (22.9) & $\begin{array}{l}2-97 \\
6-97 \\
8-98\end{array}$ & $\begin{array}{l}0.4 \\
0.3 \\
0.2\end{array}$ & 2475 & $\begin{array}{c}- \\
-20.6 \\
-21.1\end{array}$ \\
\hline VVE-10-2 (42.1) & $6-98$ & 0.2 & 2661 & -21.1 \\
\hline VVE-10-1 (59.7) & $\begin{array}{l}6-97 \\
6-98\end{array}$ & 0.0 & $\begin{array}{l}438 \\
365\end{array}$ & -11.9 \\
\hline M10S-4 (89.9) & $\begin{array}{c}10-96 \\
2-97 \\
2-98 \\
6-98 \\
7-98 \\
8-98\end{array}$ & $\begin{array}{l}0.0 \\
0.0 \\
0.0 \\
0.0\end{array}$ & $\begin{array}{c}134 \\
185 \\
259 \\
481 \\
785 \\
66\end{array}$ & $\begin{array}{c}-21.3 \\
-11.2 \\
- \\
- \\
-18.4 \\
-11.7\end{array}$ \\
\hline M10S-3 (108.8) & $\begin{array}{c}10-96 \\
2-97 \\
6-98\end{array}$ & $\begin{array}{l}0.0 \\
0.0\end{array}$ & $\begin{array}{l}160 \\
219 \\
211\end{array}$ & $\begin{array}{l}-16.0 \\
-18.8 \\
-13.4\end{array}$ \\
\hline M10S-2 (138.7) & $10-96$ & 0.0 & 376 & -9.8 \\
\hline VVE-3-3 (28.0) & $\begin{array}{c}6-98 \\
8-98 \\
10-98\end{array}$ & $\begin{array}{l}0.2 \\
0.2\end{array}$ & $\begin{array}{l}1720 \\
1947 \\
2264\end{array}$ & $\begin{array}{l}-20.9 \\
-21.2 \\
-20.8\end{array}$ \\
\hline VVE-3-2 (47.2) & $6-98$ & 0.2 & 2292 & -21.2 \\
\hline VVE-3-1 (61.0) & $\begin{array}{c}6-98 \\
10-98\end{array}$ & 0.2 & $\begin{array}{l}2383 \\
2378\end{array}$ & $\begin{array}{l}-20.8 \\
-20.6\end{array}$ \\
\hline
\end{tabular}

\begin{tabular}{|c|c|c|c|c|c|}
\hline Well \# (depth, m) & Date & $\% \mathrm{CO}_{2}$ & ppm $\mathrm{CO}_{2}$ & $\delta^{13} \mathrm{C} \mathrm{CO}_{2}$ & ${ }^{14} \mathrm{C} \mathrm{CO}_{2}$ \\
\hline VVE-6-3 (32.9) & $\begin{array}{c}2-97 \\
3-97 \\
6-97 \\
11-97 \\
6-98 \\
8-98 \\
10-98\end{array}$ & $\begin{array}{l}0.0 \\
0.2 \\
0.2 \\
0.2 \\
\\
0.1\end{array}$ & $\begin{array}{c}963 \\
1499 \\
2050 \\
1551 \\
1491 \\
\\
1535\end{array}$ & $\begin{array}{l}-14.8 \\
-17.0 \\
-19.6 \\
-17.1 \\
-19.4 \\
-19.2 \\
-18.8\end{array}$ & \\
\hline VVE-6-2 (57.0) & $\begin{array}{c}2-97 \\
3-97 \\
11-97 \\
2-98 \\
6-98 \\
8-98 \\
10-98\end{array}$ & $\begin{array}{l}0.2 \\
0.1 \\
0.2 \\
0.0 \\
\\
0.2\end{array}$ & $\begin{array}{l}1520 \\
1327 \\
1366 \\
1302 \\
1289 \\
3981\end{array}$ & $\begin{array}{c}-19.2 \\
- \\
-18.3 \\
-18.6 \\
-18.5 \\
-18.7 \\
-17.7\end{array}$ & $>5$ \\
\hline VVE-6-1 (97.5) & $11-96$ & 0.0 & 464 & -12.4 & 1.11 \\
\hline M6S-3 (111.6) & $\begin{array}{c}11-96 \\
2-97 \\
3-97 \\
6-97 \\
11-97 \\
8-98 \\
10-98\end{array}$ & $\begin{array}{l}0.0 \\
0.0 \\
0.0 \\
0.0 \\
0.0\end{array}$ & $\begin{array}{l}684 \\
709 \\
710 \\
750 \\
706 \\
634 \\
722\end{array}$ & $\begin{array}{l}-17.1 \\
-18.9 \\
-17.7 \\
-18.3 \\
-18.9 \\
-19.7 \\
-18.4\end{array}$ & 1.80 \\
\hline M6S-2 (149.4) & $6-98$ & & 978 & -19.0 & \\
\hline M6S-1 (179.2) & $\begin{array}{c}11-96 \\
2-97 \\
3-97 \\
2-98 \\
6-98 \\
8-98\end{array}$ & $\begin{array}{l}0.0 \\
0.0 \\
0.0 \\
0.0 \\
\\
0.3\end{array}$ & $\begin{array}{l}805 \\
832 \\
833 \\
812 \\
722\end{array}$ & $\begin{array}{l}-19.3 \\
-21.2 \\
-18.1 \\
-19.9 \\
-19.7 \\
-20.5\end{array}$ & 0.98 \\
\hline 1E-1 (18.4) & $\begin{array}{l}7-98 \\
8-98\end{array}$ & $\begin{array}{l}0.3 \\
0.2\end{array}$ & & $\begin{array}{l}-19.6 \\
-17.7\end{array}$ & \\
\hline $77-1-6(19.5)$ & $2-97$ & 0.2 & 2331 & -19.7 & \\
\hline VVE-1-3 (19.8) & 2-97 & 0.3 & & -22.5 & \\
\hline
\end{tabular}

